\title{
PSYCHOLOGICAL CONTRACT AS AN ELEMENT OF INTERNAL PUBLIC RELATIONS
}

\author{
Branislava KOSTIĆ ${ }^{1}$, Biljana RATKOVIĆ NJEGOVAN ${ }^{2}$ \\ ${ }^{1}$ University of Novi Sad, Faculty of Technical sciences, Department for industrial engineering and management, \\ 21000 Novi Sad, Trg Dositeja Obradovića 6, Republic of Serbia. E-mail: kosticb@uns.ac.rs, \\ ${ }^{2}$ University of Novi Sad, Faculty of Technical sciences, Department for industrial engineering and management, \\ 21000 Novi Sad, Trg Dositeja Obradovića 6, Republic of Serbia.
}

\section{Accepted 13 November, 2013}

This paper presents an exploratory study, which aims to determine the characteristics of the relationship between students and faculty representatives (who have regular functional communication with students) in order to determine the existence / non-existence of psychological contract between the faculty and students. The research is based on the belief that a healthy psychological contract, which motivates and satisfies both sides, is a motivating factor for business accomplishments and significant benefit to all participants in the process. Considering psychological contract in the context of internal public relations, this paper examines all the important elements that characterize the processes of communication within the inert public of organization (faculty). The research, which is the subject matter of this paper, was carried out on the sample of students in the third year of Engineering Management, Faculty of Technical Sciences in Novi Sad, in 2011/2012 academic year. It has shown that the basic problems regarding implementation/acceptance of psychological contract are a product of deficiencies in communication, understanding and trust between two sides amid which the psychological contract has been concluded. Thus, the problems related to the realization/acceptance of psychological contract should be resolved in the domain of internal public relations.

Keywords: internal public relations, psychological contract, faculty, students.

\section{INTRODUCTION}

\section{Internal public relations}

Internal communications or communications with internal public are part of public relations, whose roots originate from Great Britain and USA. After a long (some would say multi Millennia) period when people were considered a work force inevitably enforced to work, control and discipline, in the late 19th century capital owners gradually begin to realize that the best results could be achieved by providing better working conditions for employees. F. W. Taylor raised this statement to the level of scientific approach when he created a "scientific management" (Taylor, 1911), which gained an equal number of supporters and fierce opponents at the time of its inception. This approach of securing most efficient methods, organization and work conditions, which V. I. Lening names "scientific wringing of workers' sweat" (Keršovani, 1960), marked the establishment of management as a science. Simultaneously, however, it marked the introduction of practice, which recognizes communication with employees, as well as determination of intended interaction, as one of best means for securing profit.

Through the analysis of public relation initial stages, Dover reasonably defines three (historical) periods in the development of management communications. Therefore, he names the period from the late 19th century to the beginning of World War II, Entertainment era, characterized by the supremacy of light themes in communication with the workers (jokes, information on workers' recreation and news from their families, "newsletters published three B's - bowling, birthdays, and babies" (Dover, 1959). Basics for such communication with employees are found in (desirable) attitude that all workers are a part of 
family, despite significant differences in position, rights, and salary among owners, managers and employees. The Entertainment era was followed by Information era, during the forties of the last century, initiated by general gravity of war circumstances. This stage emphasizes the need (obligation) of informing employees about the important elements related to the company and the job itself (information about the change of time, date, payment of wages, official plans and successes of the company etc.). In this period, it was important for companies to involve employees into products optimization, and to motivate them to (productively) communicate with customers. Afterwards, Persuasion era begins in the fifties of twentieth century, which Dover characterized as a period of asymmetrical two-way communication comprising two side vertical communications, which is by content and volume disproportional regarding its direction. Almost thirty years after Dover, Grunt and Hunt add the forth era - Era of opened communications, which is characterized by (real) symmetry (Gruing and Hunt, 1984).

Bearing in mind the fact that theories hold to explain the reality, it seems that this theory is just an appropriate way to illustrate the path of practice development, which emerged as communication with employees, growing over time into Internal Public Relations. The difference between these two terms is also a difference between two practices each of which has its base, not only in history but in current reality as well. The practice of communication with employees is based on the need to ensure optimal integration of employees in the organization, its processes and goals through a variety of strategies, tactics, content and appropriate channels of communication, so that organization achieves optimal results. Thus, in theory, employee communication is defined as a planned use of communication actions in order to systematically influence employees' knowledge, attitudes and behaviour (Yeomans, 2006, p. 334).

On the other hand, the concept (and practice based on it) of Internal Public Relations, demands the adoption of generally accepted definition of public relations, which unfortunately lacks for decades. For one part of contemporary writers, public relations represent a form of business communication that is focused on developing, maintaining and promoting good working relationships between companies and interest groups (stakeholders) that operate in its environment (Van der Meiden, 1993, p. 9). Others, however, insist on getting support for the efforts organization does by encouraging public to understand and show good will towards the organization (Wilcox et al., 2006, p. 44), while a number of authors talks about public relations as a special control function with task is to identify, establish and foster mutually beneficial relationship between the organization and various public groups that may influence its success or failure (Cutlip et. al, 2006, p. 11). However, the most extensive contemporary debate about the concept of public relations is guided by the Public Relations Society of America (PRSA). In 2011/12, PRSA, the largest and most influential association of PR Managers (which is unlikely the most liberal) led an international effort to modernize the definition of public relations and replace a definition adopted in 1982 by the PRSA National Assembly. Under the "Public Relations Defined" banner, PRSA initiated a crowd sourcing campaign and public vote that produced the following definition: "Public relations are a strategic communication process that builds mutually beneficial relationships between organizations and their publics." (Smith, 2013). This definition results from a compromise between the three definitions in the previous round of voting (for members) that had the highest number of votes: a) "Public relations is the management function of researching, communicating and collaborating with publics to build mutually beneficial relationships.", b) "Public relations is a strategic communication process that builds mutually beneficial relationships between organizations and their publics.", c) "Public relations is the strategic process of engagement between organizations and publics to achieve mutual understanding and realize goals" (PRSA, 2012). The three-decadelong debate about the content of the term Public Relations, which culminated over the two year period of intense debate organized in PRSA, is probably the best illustration of the existence of very strong flows, both in science and in the field of practice development, that attempted to legalize certain, specific way of understanding and implementation of public relations through the acceptance of the (corresponding) definitions of Public Relations. The most important framework of the discussion considered the definition of Public Relations as communication between an organization and its public, which aims to achieve, maintain and develop the reputation of the organization (the definition which is, among the others, accepted by the Serbian Society for Public Relations) and the definition based on Public Relations considered as mutually beneficial relationships between organization and its public, 
which is claimed by Sam Black and other contemporary authors of "open orientation" (Black, 2003).

Discussion on the acceptance of modern definition of public relations was a reflection of debates about the nature, objectives and ethics of modern relations between the organization and its environment (Kostić, 2011), or the discussion of ethical, effective, humane and meaningful relationships between owners/managers and employees within the organization (Cameron et al., 2008).

The aforementioned discussion is very important for the subject of this paper, because the concept of psychological contract is based on the recognition of internal public relations as an important area of management, but it is also a corpus of significant relationships that are established between the owner / management and employees, on which depends success, and the very survival of modern organizations. It also means that the idea and practice of psychological contract as the basis for modern relationship between employers and employees, essentially was impossible before the establishment of modern perception of relationships with the internal public, which is evidenced by the emergence of this concept and its historical development.

Bearing in mind all disclosed, the paper starts from the understanding of public relations, which is based on the Mexican Declaration from 1978, the PRSA definition from 2012 and Black's (2003) reflection, and says that: "Public relations are a science, skill and practice of strategic communication process which builds mutually beneficial relationships between organization and its publics."

Accordingly, the internal public relations in this paper are considered as "a planned, targeted and strategically designed relations between the organization representatives and employees/ members of organizations, which aim to satisfy the interests of both sides, to match and support success / development of the organization and its employees".

\section{Public relations in the area of high education}

The paper is based on the research carried out at an institution of higher education, and it is necessary to explain the particularity of public relations in this type of organizations.
The key difference between the high education and most other organizations is reflected in the fact that a significant part of the external public of high education institutions is targeted public, which should be turned into its own internal public (as it is the case with political parties). Therefore, public relations of high education organizations are somewhat specific, because the traditional methods of communication with the external public are most closely associated with the internal public relations, which also comprise students that were a part of external public before enrolment. This feedback between internal and external public makes psychological contract between an individual (student) and the organization representatives even more important than in other organizations, being at the same time researched instantly after student's enrolment. This is the reason we have decided to conduct exploratory study in high education, rather than in classical (economic) organization, which has clearly separated external and internal public.

\section{PSYCHOLOGICAL CONTRACT - BASIC CONCEPT}

The psychological contract, in the broadest sense of the term, means the ratio of exchange between the employee and the employer, or the perception of both sides in the employment relationship organization and individuals - on the obligations contained in that relationship (Herriot and Pemberton, 1995). It is a set of mutual expectations which the contracting parties are often unaware of, but they do exist (Levinson et al., 1962), the implicit contract between the individual and his organization, which states what is given and what is expected in return in this relationship (Kotter, 1973). It includes individual beliefs that are included in conditions of a reciprocal exchange agreement between the person and the other side (Rousseau, 1989; 1995), as well as responsibility of employers to fulfil its promises (Rousseau and Greller, 1994). Argyris (1960) used the term 'psychological work contract' to describe an embeddedness of the power of perception and the values held by both parties (organization and individual) to the employment relationship.

The concept of psychological contract has achieved great importance in the theory and practice of human resource management in the last seventy years. In an earlier work on the psychological contract (Argyris 1960; Levinson, 1962; Kotter, 1973; Schein, 1965; 1978) the term 
expectations was emphasized. Recent studies (Rousseau, 1989; 1995) are focused mainly on promising nature and individual perceptions of the psychological contract. Thus, promises are defined as individual beliefs about the conditions of reciprocal exchange. In this sense, Robinson and Rousseau (1994) define the psychological contract as' an individual's belief regarding the terms and conditions of a reciprocal exchange agreement between that focal person and another party ... and the belief that some form of promise has been made and that the terms and conditions of the contract have been accepted by both parties." Thus, the psychological contract is characterized by the contracted sides, their beliefs and perceptions, implicitness, subjectivity and exchange. In terms of exchange it is necessary to define the subject of this exchange, i.e. what one party provides to the other and how the exchange is conducted.

However, the psychological contract is often violated or injured. Violation of psychological contract involves the perceived discrepancy between what was promised and what was provided in return, while the term "injury" considers an emotional reaction on the perceived gap between perceived promises and actual state of affairs. Reactions to the breach of contract can occur in the form of reduced loyalty and organizational commitment and even in behaviour opposite to organizational goals. Violation of promises made at the conclusion of the psychological contract are often made for two reasons, and they are deliberate disregard of contract and discrepancy between the agreed and what is applied in practice (Morrison and Robinson, 1997).

The psychological contract can be operational through different perspectives and expanded to other formalized relations of exchange, such as the relationship among teacher - student - organization (university). This relationship means 'the implicitly and tacitly held expectations of agreement \& the' contractual 'relationship between students and lecturers about the nature of their relationship and exchange in the process of education' (Charlton et al., 2006). Researches Bordia et al. (2010), Charlton et al. (2006), Nesbit and Burton (2006), Alexitch (2002), Brems et al. (1994) confirmed the importance of psychological contract for learning quality and implicit cognitive and behavioural expectations within students' perceptions.
Research on students' attitudes towards psychological contract with their teachers and faculty, whose results are presented in this paper shows that the psychological contract, which clearly formulates the nature of exchange and respect from both sides of the "contractual" relation, improve institutional climate, contributes to higher motivation and commitment of students, development of social competence and a sense of belonging to academic community.

\section{RESEARCH RESULTS AND DISCUSSION}

The study was planned and conducted as exploratory, because it is: a) under-research area of management, which requires an interdisciplinary approach, b) observing psychological contract as an important element of internal public relations, understood as a set of structured, consciously and systematically built relationships between owners / managers and employees in the organization, which aims to satisfy the interests of both sides. After this phase (which was completed in 2012) the preparation for fundamental research has been conducted, which is based on the findings of the exploratory study whose findings are presented in this paper.

The research was carried out on the sample of students from the Faculty of Technical Sciences in Novi Sad, which was selected due to the highest representation of various fields of study in Serbia. Faculty of Technical Sciences has 88 accredited study programs at all levels of studies, covering technical and technological, mathematical sciences, art and medical field - through interdisciplinary studies.

\section{Subject/goal}

The subject of the study was to determine the presence / absence of the elements of psychological contract between students and faculty / faculty representatives, and to assess the influence of the existence / non-existence of a clear psychological contract on students' motivation and their attitude towards work / study and the representatives of the faculty.

The goal of the study was to determine the existence of psychological contract between the faculty and students, and establish the relation between the content of psychological contracts and relationships, behaviours and expectations of students towards the faculty as an institution, faculty representatives and the faculty and 
fulfilment of their own obligations in terms of learning / achieving a given goal.

\section{Hypothesis}

The basic premise from which we set out in this exploratory study was that the existence of psychological contract, the content / character and the degree of realized expectations, significantly influence the processes of organizational socialization, but also influence the extent and quality of involvement in the organization and the motivation for achievements and their realization.

Second important assumption which defined our study was that psychological contract should be viewed primarily in terms of relation with internal public, both because of its dominant content and because of its form, means of creation/ establishment, the basis on which it arises and how it is implemented.

\section{Sample}

The research was conducted in the winter semester $2011 / 2012$, on a sample of students of the third year of the Faculty of Technical Sciences in Novi Sad, Department of Engineering Management, which enrolled Faculty in 2009/2010 academic year. The sample included all students of this department, who were studying from the budget and on the day of the interview were present in class (136 out of 148 students). The structure of the sample comprises $59 \%$ female and $41 \%$ male examinees.

\section{Research method}

The research was conducted through testing, using the techniques of interview, based on questionnaires which included questions in which the subjects are required to rate the quality or degree of presence of an attitude / claim. Students were interviewed at their workspace, for 30 minutes.

\section{Research results}

\section{Expectations}

More than one third of students were unable to clearly define the extent of their familiarity with the work of faculty representatives, (38\%); a fifth claimed it was not entirely familiar with the modus operandi of the Faculty (21\%), while $6 \%$ of the students were unaware of the modus operandi of the faculty. Only $6 \%$ of the students were fully acquainted with the work of faculty representatives, while $26 \%$ of the students were well-informed. The data indicate relatively undefined or inadequate expectations of students, formed before enrolment. In addition, $64 \%$ of students claimed that the first information about the faculty were not received from faculty representatives (through the media, the Internet, "Open faculty days", etc), but from other sources, which indicates a possible cause of their poor awareness.

\section{Awareness of psychological contract}

Despite the initial lack of defined expectations from faculty, most students (56\%) had a clear awareness that there is a healthy psychological contract between the students and faculty, which is based on mutual understanding. However, $32 \%$ of the students were unaware of this psychological contract, while $12 \%$ were insecure in this regard. The data indicate that the faculty failed to achieve mutual understanding with $32 \%$ of students, within three years of their study. One reason for these results may be the lack of high prior expectations of students regarding the manner of work at the university, although significant portion of these undefined expectations should be suppressed by subsequent experiences while studying.

On the other hand, a significant majority of students $(88 \%)$ found that the existence of psychological contract, which is based on mutual understanding between the students and faculty, increases student motivation, which in the context of the data presented regarding the achieved level of understanding speaks about disillusionment for about $20 \%$ of students who wanted to achieve mutual understanding with the faculty, but find that it is unlikely to accomplish.

The percentage of students who felt that the understanding between faculty and students is an important factor of student's motivation completely correlated with the percentage of students who believe that regular attendance on lectures and exercises are important for their success and final outcome of their education.

One of the main obstacles for successful establishment of a healthy psychological contract between the students and faculty can be negative attitude of students regarding "profitability" of work investment and relation of effortachievement. Consequently, students' attitudes 
regarding three questions are especially significant: how much effort requires studying, whether student's success depends on the effort invested, as well as what the correlation between invested effort and enrolment on the faculty is. Most students think that the study program requires a lot of hard work and time to meet all student's obligations (73\%), while $82 \%$ believe that student's success depends on the effort (only 3\% of the students claim that there is no correlation). In contrast to the correlation in the attitudes regarding these two issues, the research results indicate a negative attitude towards the relationship between effort and enrolment: up to $15 \%$ of the students claimed that there is no expected relationship, 53\% of the students thought that there is correlation, while only $12 \%$ of the students were firmly convinced that there is such correlation.

\section{The relationship between students and teachers}

Only $9 \%$ of the students considered that the following statement is false "Engagement of students in lectures / exercises is accompanied by proper care of teachers," while $47 \%$ agreed with it and $29 \%$ strongly agreed with the statement. On the other hand, only $9 \%$ of the students thought that the faculty fully met their expectations in terms of clarity of their lectures and corroboration of understandable and available literature, $47 \%$ confirmed that their expectations were met, 23\% lacked clear attitude, while $15 \%$ claimed that their expectations on these features of lectures remain poorly satisfied, or - unsatisfied at all (6\%). Most of the students had the impression that their teachers are available to them and that they can address them, but they admit that they themselves do not help teachers to understand their needs (lack of open two-way communication). Accordingly, the students' impression is that the teachers pay poor attention to students' expectations (more than half of the students), which is the most negative attitude presented in the research $(18 \%$ of the students claimed that the teachers do not pay attention to their expectations, $47 \%$ could neither agree nor contradict mentioned opinion, while only $35 \%$ of the students thought that teachers pay attention to their expectations.

Defined expectations of students in relation to the faculty have been met by $53 \%$ of the examinees, $9 \%$ were completely filled, while for $15 \%$ of the students they were not met at all, and 23\% did not have a clearly defined position. Nevertheless, $73 \%$ of the students said they felt like members of the faculty community, as opposed to $15 \%$ who are unlikely to feel that way.

\section{CONCLUSIONS}

The research has shown that the basic problem related to the realization / acceptance of psychological contract is a product of deficiencies in communication, understanding and trust between two sides, between students and faculty representatives. Consequently, the basic conclusion of the research is that the problems (or - their significant part) regarding realization/acceptance of psychological contract can be resolved in the domain of internal public relations. This finding directed us towards further research and development of an optimal model of communication in public relations in general, and especially - in dealing with internal PR, where it is excessively neglected that the party which is opposed to the owner and management should not be merely perceived as a "resource" because it represents individuals, whose motivation, satisfaction and readiness for engagement largely influence the fate of the organization.

The results suggest the existence of a healthy psychological contract between the students and faculty, which most of the students are aware of and support it, as it is based on mutual understanding. Accepting the reality of this psychological contract by the students was directly correlated with their perception of relation between effort and achievement, as well as teachers' attitude towards the teaching subject, the students' need to understand subject-matter and teachers' willingness to clarify it.

In terms of establishing a psychological contract between the students and faculty (faculty representatives and faculty as an institution), our research points out several existing obstacles whose removal means an increase of the percentage of satisfied, motivated and successful students.

Firstly, it is teachers' attitude towards students' expectations, because a significant percentage of the students claimed that teachers are insufficiently interested in their expectations, which proved to be one of the largest obstacles while establishing meaningful relationship between the students and teachers as well as students greater confidence in the reality of the psychological contract between them and the faculty. 
Secondly, there is an obstacle related to the early establishment/acceptance of psychological contract by the students, which results from the lack of students' awareness about teaching methodology at higher education, which slows down/delays acquisition of awareness of the existence of psychological contract.

The third obstacle is composed of students' reduced confidence in faculty due to the method of entry; certain percentage of the examinees said that there was clear correlation between the enrolment and their effort, but more students were convinced that such correlation does not exist at all.

Our initial assumption that psychological contract should be regarded as an element of internal public relations, was confirmed to the fullest extent possible, because all the obstacles in establishment/acceptance of the psychological contract were essentially the result of poorly designed or poorly implemented relationship with students as a target group of internal public . Using modern methods, strategies and tactics of optimization of internal communications, all the ascertained obstacles can be quickly removed. The only obstacle that is only partially dependent on the methods and techniques of internal communication is reduced confidence in the fairness of enrolling in faculty. In the framework of communication solutions, it would be necessary to enhance the frequency and channels of providing information on the scoreboard and make it possible to verify the results of each student's enrolment both for themselves and for the others. However, this problem should not be regarded only as a communicational, but the findings should be taken as a warning that the students have some doubts, or at least show reduced confidence in the faculty, and thus, the reality of these assumptions should be fully investigated.

As students perceive a very high value of understanding as an essential element of the psychological contract, it is clear that in the coming research we should further explore the other elements of the psychological contract, the consequences of its existence/non-existence, the role of psychological contract in different engagements and students' achievements, as well as possible models for overcoming obstacles in creation/acceptance of the psychological contract.

\section{REFERENCES}

Alexitch, L. R. (2002). The role of help-seeking attitudes and tendencies in students' preferences for academic advising. Journal of College Student Development, 43(1), 5-19.

Argyris, C. (1962). Understanding organizational behavior. Homewood, IL: Dorsey.

Black, S. (2003). The Essentials of Public Relations [in Serbian]. Beograd: Clio.

Bordia, S., Hobman, E. V., Restubog, S. L., \& Bordia, P. R. (2010). Advisor-Student Relationship in Business Education Project Collaborations: A Psychological Contract Perspective. Journal of Applied Social Psychology, 40(9), 2360-2386.

Brems, C., Baldwin, M. R., Davis, L., \& Namyniuk, L. (1994). The imposter syndrome as related to teaching evaluations and advising relationships of university faculty members. Journal of Higher Education, 65(2), 183-193.

Cameron, G. T., Wilcox, D. L., Reber, B. H., \& Shin, J. H. (2008). Public relations today: Managing competition and conflict. Boston, MA: Allyn \& Bacon.

Charlton, J. P., Barrow, C., \& Hornby-Atkinson, P. (2006). Attempting to predict withdrawal from Higher Education using demographic, psychological and educational measures. Research in PostCompulsory Education, 11(1), 31-47.

Dover, C. J. (1959). The Three Eras of Management Communication. Journal of Communication 9(4), 168-172.

Grunig, J., \& Hunt, T. (1984). Managing Public Relations. New York: Holt, Rinehart \& Winston.

Herriot, P., \& Pemberton, C. (1995). New Deals: The Revolution in Managerial Careers. Chichester: Wiley.

Cutlip, S. M., Center, A. H., \& Broom, G. M. (2006). Effective Public Relations [in Serbian]. Beograd: Službeni glasnik.

Keršovani, O. (1960). Izbor članaka. Beograd: Kultura. Kostić, B. (2011). New Ethical Challenges in the Study and Practice of Public Relations at the Beginning of the Twenty-First Century. Paper presented at the 3 . Annual International Conference on Education and New Learning Technologies EDULearn11, 4-6 July, Barcelona.

Kotter, J. P. (1973). The Psychological Contract: Managing the Joining up Process. California Management Review, 15(3), 91-99.

Levinson, H., Price, C. R., Munden, K. J., \& Solley, C. M. (1962). Men, management, and mental health. Cambridge; MA: Harvard University Press.

Morrison, E. W., \& Robinson, S. L. (1997). When employees feel betrayed: A model of how psychological contract violation develops Academy of Management Review, 22(1), 226-256.

Nesbit, P. L., \& Burton, S. (2006). Student justice perceptions following assignment feedback. Assessment and Evaluation in Higher Education, 31(6), 655-670.

PRSA. What is Public Relations? PRSA's Widely Accepted Definition, Retrieved February, 2013, from http://www.prsa.org/AboutPRSA/PublicRelationsDe fined 
Robinson, S. L., \& Rousseau, D. M. (1994). Violating the psychological contract: Not the exception but the norm. Journal of Organizational Behavior, 15(3), 245-259.

Rousseau, D. M. (1989). Psychological and Implied Contracts in Organizations. Employee Responsibilities and Rights Journal, 2(2), 121-139.

Rousseau, D. M. (1995). Psychological Contracts in Organizations: Understanding Written and Unwritten Agreements. Thousand Oaks, CA: Sage.

Rousseau, D. M., \& Greller, M. (1994). Human Resource Practices: Administrative Contract Makers. Human Resource Management, 33(3), 385401.

Schein, E. H. (1965). Organizational Psychology. New Jersey: Englewood Cliffs.
Schein, E. H. (1978). Career Dynamics: Matching Individual and Organisational Needs. Reading, MA: Addison-Wesley.

Smith, D. R. (2013). Strategic Planning for Public Relations (4th ed.). New York: Routledge.

Taylor, F. W. (1911). Principles of Scientific Management. New York, USA and London, UK: Harper \& Brothers.

Van der Meiden, A. (1993). Public Relations [in Serbian]. Novi Sad: Prometej.

Wilcox, D. L., Cameron, G. T., Ault, F. H., \& Agee, W. K. (2006). Public Relations [in Serbian]. Beograd: CID Ekonomski fakultet

Yeomans, L. (2009). Internal Communication. In R. Tench \& L. Yeomans (Eds.), Exploring Public Relations (pp. 316-336). Harlow: FT/Prentice Hall. 